\title{
HOPE YET FOR THE AUTOMOBILE DEALERS' DAY IN COURT ACT: MARQUIS $V$. CHRYSLER CORP.
}

The Automobile Dealers' Day in Court Act (ADDCA), ${ }^{1}$ enacted in 1956 , created a new cause of action for automobile dealers. ${ }^{2}$ Under ADDCA, dealers may sue automobile manufacturers ${ }^{3}$ in federal court for damages caused by the manufacturers" failure to act in "good faith" in coinplying with terms of the franchise agreements, or in terminating or not renewing their dealers' franchises. ${ }^{4}$

THE FOLLOWING CITATIONS WILL BE USED IN THIS NOTE:

H.R. REP. No. 2850, 84th Cong., 2d Sess. (1956), reprinted in [1956] U.S. CODE CONG. \& AD. NEws 4596 [hereinafter cited as H.R. REP. No. 2850];

Brown, A Bill of Rights for Automobile Dealers, 12 B.C. INDus. \& Com. L. Rev. 757 (1971) [hereinafter cited as Brown].

1. 15 U.S.C. $\S \S 1221-1225$ (1976). The ADDCA has withstood several constitutional challenges. In Volkswagen Interamericana, S.A. v. Rohlsen, 360 F.2d 437, $444-45$ (Ist Cir.), cert. denied, 385 U.S. 919 (1966), the court rejected the contention that the ADDCA is unconstitutional on the grounds of vagueness and of alleged arbitrary distinctions unrelated to public interest. In Blenke Bros. v. Ford Motor Co., 203 F. Supp. 670, 672-73 (N.D. Ind. 1962), the court held that "good faith" is a constitutionally ascertainable standard within the provisions of the fifth amendinent, that the ADDCA does not violate the standards of the right of freedoin to contract, and that the Act is not invalid as arbitrary and discrininatory in violation of the fifth ainendment. For general discussions of the ADDCA, see Kessler, Automobile Dealer Franchises: Vertical Integration by Contract, 66 YALE L.J. 1135, 1171-89 (1957); Macaulay, Changing a Continuing Relationship Between a Large Corporation and Those Who Deal with It: Automobile Manufacturers, Their Dealers, and the Legal System (pts. 1-2), 1965 Wis. L. REv. 483, 741; Comment, The Automobile Dealer Franchise Act of 1956-An Evaluation, 48 CORNELl L.Q. 711 (1963); Note, Statutory Regulation of Manufacturer-Dealer Relationships in the Automobile Industry, 70 HARV. L. REV. 1239 (1957).

2. The ADDCA defines "autonobile dealer" as "any person, partnership, corporation, association, or other form of business enterprise . . . operating under the terms of a franchise and engaged in the sale or distribution of passenger cars, trucks, or station wagons." 15 U.S.C. $\S 1221$ (c) (1976).

3. The ADDCA defines "automobile manufacturer" as

any person, partnership, corporation, association, or other form of business enterprise engaged in the manufacturing or assembling of passenger cars, trucks, or station wagons, including any person, partnership, or corporation which acts for and is under the control of such manufacturer or assembler in connection with the distribution of said autonnotive vehicles.

15 U.S.C. \& 1221(a) (1976).

4. 15 U.S.C. $\$ 1222$ (1976). The word "termination" as used in this Note shall refer both to 
Congress had two purposes in enacting ADDCA. First, it intended that ADDCA would "balance the power now heavily weighted in favor of automobile manufacturers ...."s Courts interpreting ADDCA have recognized that ADDCA's major purpose is to balance the bargaining power of the inanufacturer and the dealer. 6 Second, Congress, realizing "that traditional contractual concepts are no longer adequate to protect the autoinobile dealers under their franchises," intended that ADDCA would "assure a dealer the opportunity to secure a judicial determination irrespective of contract terms as to whether the automobile manufacturer has failed to act in good faith . . . ."8

By granting the dealer a cause of action against the manufacturer for the failure of the latter to act in good faith, the Act was intended to implement Congress' desire to balance the bargaining power between the parties. Congress gave greater particularity to the type of conduct for which the inanufacturers would be liable by defining the term "good faitlu" as:

[T] he duty of each party to any franchise . . . to act in a fair and equitable manner toward each other so as to guarantee the one party freedom froin coercion, intimidation, or threats of coercion or intimidation from the other party: Provided, That recommendation, endorsement, exposition, persuasion, urging or argument shall not be deemed to constitute a lack of good faith. ${ }^{9}$

In this definition, the clauses beginning with "so as to" and "Provided, That" can reasonably be construed respectively as "descriptive" and "exclusive" provisions. "Fair and equitable" conduct by one party is the kind of conduct that provides the other party with, inter alia, freedom fron coercion and intimidation. Lack of good faith does not include mere recommendation or persuasion. This reading of the

termination of the franchise before the contractual expiration date and to nonrenewal of the franchise at such date.

5. Act of Aug. 8, 1956, Pub. L. No. 84-1026, Preamble, 70 Stat. 1125. The legislative history of the Act indicates that Congress was concerned with the "[c]oncentration of economic power in the automobile manufacturing industry" and hoped that ADDCA would "remedy the manifest disparity in the ability of franchised dealers of automotive vehicles to bargain with their manufacturers." H.R. REP. No. 2850, at 4596-97; Brown 760. Shares of the total U.S. new passenger car sales in 1978 were as follows: General Motors-47.6\%; Ford-22.8\%; Imports-17.9\%; Chrysler10.1\%; and American Motors-1.5\%. National Automobile Dealers Association, NADA Data for 1979 , at 4 (1979).

6. See, e.g., Randy's Studebaker Sales, Inc. v. Nissan Motor Corp., 533 F.2d 510, 515 (10th Cir. 1976); Hanley v. Chrysler Motors Corp., 433 F.2d 708, 710 (10th Cir. 1970); Woodard v. General Motors Corp., 298 F.2d 121, 127 (Sth Cir. 1962), cert. denied, 369 U.S. 887 (1962); Swartz v. Chrysler Motors Corp., 297 F. Supp. 834, 838-39 (D.N.J. 1969).

7. H.R. REP. No. 2850 , at 4597.

8. Alfieri v. Willys Motors, Inc., 227 F. Supp. 627, 629-30 (E.D. Pa. 1964); see H.R. REP. No. 2850 , at 4596 .

9. 15 U.S.C. $\S 1221(\mathrm{e})(1976)$. 
definition adequately serves the purpose of ADDCA while permitting the manufacturer the leeway needed to promote dealer effectiveness fairly and honestly. The qualifications in the definition of "good faith" reflect Congress' apprehension that, without the definition, the balance of bargaining power might tilt too far in the dealer's favor. ${ }^{10}$

Unfortunately, the "so as to" qualification in the definition is ambiguous; the qualification can also be interpreted as an "exclusive equation" or a "definition within a definition." Under such an interpretation, "good faith" would nean only the duty of each party to refrain froin coercing, intimidating, or threatening to coerce or intimidate the otlier party. Defining "good faith" in this restricted maimer would hinder the achieveinent of ADDCA's purpose. It is possible to imagine various kinds of unfair and inequitable conduct, neither coercive nor intimidating, which stein from and bolster the inanufacturer's superior bargaining position." 1 By excluding such kinds of conduct from the purview of "failure to act in good faith," the Act would certainly fall short of its goal of equalizing bargaining power. The legislative history does little to correct the ambiguity of the "so as to" clause. ${ }^{12}$

Altlough ADDCA is "class legislation," it is important to recognize the substantial part that the select conmunity to which it is directed plays in the American economy. In 1978, 11,307,547 new passenger cars, with a total sales value of $\$ 127.9$ billion, were sold in the United States. ${ }^{13}$ The 28,850 franchised new car dealers accounted for sixteen percent of the nation's total retail sales. ${ }^{14}$ Furthermore, the problems and abuses that exist in the autonotive franchise industry frequently are representative of those that occur in franchising generally. ${ }^{15}$

10. Two conflicting policies underlie the ADDCA: "protecting the dealer but [at the same time] preserving the manufacturer's ability to make business decisions." Chinetti-Garthwaite lmports, Inc. v. Ferrari Societa Per Azioni Esercizio Fabbriche Automobili E Corse, 463 F. Supp. 73, 77 (E.D. Pa. 1978). The legislative history demonstrates that Congress did not want the Act to prevent inanufacturers from ending franchise relationships with unsatisfactory dealers. See text accoinpanying note 50 infra.

11. For example a inanufacturer, without just cause, might refuse to deliver or might deliver witl inordinate delay cars that the dealer has ordered, or the manufacturer might establish without just cause a new dealership close to the dealer so that his sales are thereby lint.

12. The House Report explains that

[t]he term "fair and equitable" as used in the bill is qualified by the term "so as to . . .." In each case arising under this bill, good faitl must be determined in the context of coercion.... Each party to an automobile franclise would have a special obligation to guarantee the other party freedom from coercion ....

H.R. REP. No. 2850, at 4603 (emphasis added).

13. National Automobile Dealers Association, supra note 5, at 4.

14. Id. 14-15.

15. See generally H. Brown, Franchising: Realities and Remedies (2d ed. 1978). 
After a brief discussion of the nature of the automobile franchise relationship, this Note will analyze the traditional application of ADDCA in cases in which dealers have alleged that manufacturers' had failed to act in good faith, especially in terminating or in not renewing their franchises. ${ }^{16}$ The analysis will show that courts have normally insisted that "failure to act in good faith" under ADDCA means solely "coercion, intiunidation or threats" thereof. The courts have deferred to the contractual terms of the franchise agreement and to the business judgment of the manufacturers. This attitude of deference has resulted in a merely superficial examination of the manufacturer's performance under the franchise agreement and of its decision to terminate the relationship.

This Note will next discuss the 1978 case of Marquis v. Chrysler Corp. ${ }^{17}$ in which the court departed froin traditional attitudes and guidelines, and instead took a closer look at the franchise relationship, the motives of the inanufacturer, and the dealer's point of view, both when the franchise was in force and when it was termmated. Since the new approach taken by the Marquis court is a mmority view, this Note concludes by considering possible amendments to ADDCA. These amendments are suggested as means of better and more clearly implementing the major objective of $\mathrm{ADDCA}$-equalization of bargaming power between manufacturer and dealer.

\section{The Automobile Franchise Relationship}

Alinost all new cars are sold to the public through independently owned, franchised dealerships. ${ }^{18}$ According to one observer, the goal of the automobile franchise relationship is simply "to sell new autounobiles so that profits are produced for both the manufacturer and the dealer." 19 To achieve this objective, both the manufacturer-franchisor

16. Most ADDCA cases concern termination of the franchise, and termination serves as a good focal point for the examination of the effectiveness of the ADDCA. Termination usually makes the dealer vulnerable to more severe financial loss than he could suffer through coercive bad faith practices conducted by the manufacturer in the operating phase of the dealership. See text accompanying note 30 infra. Moreover, termination is frequently the inevitable culmination of these bad faith tactics. The termination cases under the ADDCA often expose the conflicting interests of the manufacturer and the dealer and the pronounced imbalance of bargaining power between the two parties.

17. 577 F.2d 624 (9th Cir. 1978).

18. "Of all the retailing structures possible, the automobile manufacturers have settled on the franchised dealership, with direct wholesale shipments from the manufacturer to the dealer, as the preferred form." L. White, The Automobile InduSTRy Since 1945, at 136 (1971). See also General Motors Corp., Competition and the Motor Vehicle Industry 81 (1974).

19. Macaulay, supra note 1 , at 489 . Despite this identity of interest, conflict arises when "different business strategies will produce varying payoffs for each party." Id. 491. Manufactur- 
and the dealer-franchisee must contribute to the franchise system. The automobile manufacturer makes two fundamental contributions. First, it provides the dealer with a marketable product-an automobile that is the result of design and engineering, quality production, and market planning. In addition to this, the manufacturer provides advertising, a trade name, nationwide service facilities, a competitive price, and training and advice to the dealer's managers, salesmen, and mechanics. Second, the manufacturer provides the dealer the opportunity to sell financing, msurance, accessories, repair parts, and service. In return, the dealer provides an outlet for the sale and representation of the manufacturer's goods by investing in plant, equipment, inventory, and sales promotion, and the dealer devotes the skills and the risk-taking needed in liandling the sales of new and used cars. ${ }^{20}$ Besides performing as retail sellers, franchised dealers provide service facihities and stock replacement parts. ${ }^{21}$

In order to cover their costs, return a profit to shareholders, and provide transportation to the public at an acceptable price, the manufacturers must sell huge quantities of automobiles. ${ }^{22}$ The franchising systein gives the manufacturer the control and supervision needed to assure that its sales goals can be met. The privileges extended to dealers of buying at wholesale prices and using the manufacturer's name are accompanied by the responsibility to construct and maintain facilities according to the manufacturer's wishes and to strive to achieve the sales targets establislied by the manufacturer. ${ }^{23}$

The need to protect the reputation of their trademarks and to maintain or strengthen their franchise marketing networks leads manufacturers to "pusli" soine dealers who are not perforinm satisfactorily. ${ }^{24}$ Likewise, because automobile dealers must depend on the powerful "Big Three" oligopoly for their supply of cars, the dealers have relatively little bargaining power. ${ }^{25}$ Accordingly, they usually ac-

ers usually prefer high-volume, low-profit sales, whereas the dealer normally prefers to make a larger profit on each car he sells. The manufacturer is economically committed to sell all of the various models it produces, but the dealer would rather handle only the popular lines. There is also a difference in interest regarding the proper capitalization for the busimess. Id. 491-92.

20. Id. 489-90.

21. "Reliable service is an essential factor in selhing cars and trucks. . . GM continues to consider the quality of dealer service one of the most sensitive and critical areas of the automotive business." General Motors CoRP., supra note 18, at 82-83.

22. Macaulay, supra note 1 , at 504 .

23. L. White, supra note 18 , at 137.

24. "Due to the importance to customers of service and parts availability, automotive companies must work constantly to improve the quahity of their dealers' service facihties . . . GENERAL MOTORS CORP., supra note 18, at 82-83.

25. Brown 760; see Macaulay, supra note 1, at 493-96; see note 5 supra. 
cept without change the "selling agreement," an elaborate franchise contract that is drafted in "legalese" by the manufacturer's lawyers. This imbalance in bargaining power often results in bitter dealer coinplaints regarding manufacturer control and abuses in the "operating," "capital," and "administrative" areas of the franchise relationship. ${ }^{26}$

An essential part of the franchise relationship is the manufacturer's right to terminate it. 27 The termination right serves to protect the value of the inanufacturer's trademark for the benefit of other franchisees in the system and to prevent the distribution of inferior products and services to consumers. In addition, termination of a dealer is the means by which a manufacturer can implement a decision it makes to withdraw a product line from a certain geographical market. ${ }^{28}$ There are several other reasons why an auto inanufacturer might decide to terminate a franchise: a dealer may not be selling enough cars; a dealership may have sinaller or older facilities or less capital than the manufacturer thinks is appropriate; the business may be distupted by personal problems, such as the death of a dealer or management conflicts; the manufacturer may wish to punish a dealer for taking on the franchise of another maker's car or for buying parts from an independent seller rather than from the manufacturer; a better dealer may be available; or a dealer may be personally disliked by certain officers or representatives of the manufacturer who wish to do him harm. ${ }^{29}$

Althouglı arbitrary and unfair operating conditions imposed by a manufacturer on a dealer frequently limit the dealership's profitability, termination renders the dealer vulnerable to more severe economic loss. The terminated franclisee might well lose his entire cash investment in the franchise. The dealer will run into great problems in trying to salvage this investment. It is very difficult for a cancelled dealer to obtain a franchise froin another manufacturer or to sell his building, lots, inventory, and goodwill to another dealer..$^{30}$

Manufacturers usually agree to soften the harsh blow of termina-

26. Brown 760-76.

27. Franchise agreements normally provide explicitly for a manufacturer's termination of a dealcrship for various reasons imcluding transfer of the dealership interest, insolvency of the dealer, misrepresentation to the manufacturer, and death or incapacity of the principal owner. More importantly, the agreement usually allows the manufacturer to terminate for failure of the dealer to fulfill his responsibilities regarding dealership location, facilities, service, or sales. See Chrysler Motors Corp., Direct Dealer Agreement (1971); Ford Motor Co., Ford Sales and Service Agreement If 17(c) (1976); Chevrolet Motor Div., General Motors Corp., Dealer Sales and Service Agreement (1975).

28. H. BRown, supra note 15, at 204.

29. Macaulay, supra note 1 , at 563 ; id. pt. 2, at 774 . Termination for most of these reasons may be undertaken under the terms of the typical franchise agreement. See note 27 supra.

30. Macaulay, supra note 1 , at 495 . 
tion by buying up the cancelled dealer's tangible assets. ${ }^{31}$ However, these agreements do not provide for compensation to the dealer for the capital investment he has made in the dealership and the coinmercial goodwill he has created in his enterprise. ${ }^{32}$ Manufacturers have also initiated internal appeals procedures by which dealers may voice their opposition to termination of their franchises..$^{33}$ It is difficult to evaluate the present effectiveness of these plans, but in the past they have proved to be of little aid to dealers complaining of what they feel are unjustifiable or unfair terminations. ${ }^{34}$

A dealer who beheves he has been unfairly treated or terminated by his manufacturer and who has been unsuccessful in pleading his case directly to his franchisor may resort to litigation on various grounds. If the unfair treatment or termination results froin the manufacturer's superior bargaining position and demonstrates the manufacturer's failure to act in good faith, the dealer may sue the manufacturer in federal court for violation of the ADDCA.

\section{TRADITIONAL ADDCA INTERPRETATION}

\section{A. The Definition of Good Faith.}

Section 2 of the ADDCA grants an automobile dealer the right to recover the damages by him sustained and the cost of suit by reason of the failure of said automobile manufacturer . . to act in good faith in performing or complying with any of the terms or provisions of the franchise, or in terminating, canceling, or not renewing the franchise with said dealer . . . .35

The courts have shown some hberality in construmg this provision of the ADDCA. Though section 2 provides only for the recovery of damages, federal courts have held that this does not prevent courts from granting injunctions. ${ }^{36}$ Moreover, though section 2 on its face suggests

31. Under the franchise agreements of the "Big Three" auto factories, the manufacturer agrees to buy from the terminated dealer new cars, parts and accessories, signs and special tools, and to assist the dealer in the post-termination disposition of the dealership premises and facilities. Chrysler Motors Corp., supra note 27, at ๆๆ 21-23; Ford Motor Co., supra note 27, at ๆๆ 2122, Chevrolet Motor Div., supra note 27, at 24-30.

32. One author suggests that the manufacturers mistakenly believe that their contributions alone produce the goodwill associated with the auto dealership. Brown 767-70.

33. See Chrysler Motors Corp., Chrysler Motors Review Board Procedure (1967); Ford Motor Co., Plan and Rules of Arbitration (1976); General Motors Corp., The General Motors Dealer Relations Umpire Plan (1974).

34. See Kotula v. Ford Motor Co., 338 F.2d 732 (8th Cir. 1964), cert. denied, 380 U.S. 979 (1965); Brown 773-75.

35. 15 U.S.C. § 1222 (1976).

36. Semmes Motors, Inc. v. Ford Motor Co., 429 F.2d 1197, 1206 n.14 (2d Cir. 1970); Clifford Jacobs Motors, Inc. v. Chrysler Corp., 357 F. Supp. 564, 573 (S.D. Ohio 1973); Miller Plymouth Center, Inc. v. Chrysler Motors Corp., 286 F. Supp. 529, 531 (D. Mass. 1968). 
that failure to act in good faith in the case of termination can occur only when the manufacturer terminates the franchise, federal courts have established that an ADDCA action may also be brought when a dealer has been coerced into "voluntary" termination. ${ }^{37}$

In contrast, the courts have strictly interpreted the definition of good faith in section 1 . Section 1 defines good faith to be "the duty of each party to any franchise . . . to act in a fair and equitable inanner toward each other so as to guarantee the one party freedom from coercion, intinidation, or threats of coercion or intimidation froin the other party . . ." 38 It is certainly possible to read this definition simply as "the duty of each party . . . to act in a fair and equitable manner toward each other." The qualification "so as to guarantee the one party freedoun from coercion" might describe only one objective of such fair and equitable behavior. Nonetheless, the courts have consistently applied a conjunctive test- "failure to act in good faith" must include unfair/inequitable conduct and actual or threatened coercion. ${ }^{39}$ Furthermore, in order to prove coercion, the dealer must establish three elements: a wrongful demand, a threat to impose sanctions (e.g., termination) if he does not comply with the demand, 40 and damages resulting from the dealer's coinphiance with the wrongful demand or froin the sanctions imposed for failure to coinply. ${ }^{41}$ In termination cases the courts have required the dealer to prove a wrongful demand, for which noncompliance will result in termination, and a causal connection between termination and the dealer's resistance to the wrongful demand. ${ }^{42}$

37. Hanley v. Chrysler Motors Corp., 433 F.2d 708, 712 (10th Cir. 1970); American Motors Sales Corp. v. Semke, 384 F.2d 192, 195 (10th Cir. 1967).

38. 15 U.S.C. $\S 1221$ (e) (1976) (emphasis added). The term "coercion" as used in this Note shall refer to coercion, intimidation, or threats of either.

39. See Sherman v. British Leyland Motors, Ltd., 1979-2 Trade Cas. If 62,784 (9th Cir. 1979); Francis Chevrolet Co. v. General Motors Corp., 1979-2 Trade Cas. I 62,760 (8th Cir. 1979); Ed Houser Enterprises, Inc. v. General Motors Corp., 595 F.2d 366, 369 (7th Cir. 1979); Fray Chevrolet Sales, Inc. v. General Motors Corp., 536 F.2d 683, 685 (6th Cir. 1976) (citing cases); Randy's Studebaker Sales, Inc. v. Nissan Motor Corp., 533 F.2d 510, 514 (10th Cir. 1976); Volkswagen Interamericana, S.A. v. Rohlsen, 360 F.2d 437, 442 (1st Cir.), cert. denied, 385 U.S. 919 (1966).

40. Sanctions that the automobile franchisor may impose on the franchisee include withholding delivery of cars, establishing nearby competing dealerships, and, most importantly, termination.

41. See Autohaus Brugger, Inc. v. Saab Motors, Inc., 567 F.2d 901, 911 (9th Cir.), cert. denied, 436 U.S. 946 (1978); Fray Chevrolet Sales, Inc. v. General Motors Corp., 536 F.2d 683, 685 (6th Cir. 1976); Carrozza v. Webber Chevrolet Co., 1978-1 Trade Cas. If 61,982 (D.R.I. 1978); Berry Bros. Buick, Inc. v. General Motors Corp., 257 F. Supp. 542, 546 (E.D. Pa. 1966), affd, 377 F.2d 552 (3d Cir. 1967).

42. Ed Houser Enterprises, Inc. v. General Motors Corp., 595 F.2d 366, 371 (7th Cir. 1979); Autohaus Brugger, Inc. v. Saab Motors, Inc., 578 F.2d 901, 911 (9th Cir.), cert. denied, 436 U.S. 946 (1978). See also Fray Chevrolet Sales, Inc. v. General Motors Corp., 536 F.2d 683, 685 (6th 
The courts' narrow interpretation of the definition of good faith and their establishment of the eleinents of coercion have denied dealers ADDCA protection from entirely arbitrary or blatantly inequitable ternuination when such termination is not linked to a wrongful demand and threat by the inanufacturer. ${ }^{43}$ The courts' conception of good faith and coercion might discourage manufacturers from making demands backed up with a threat of termmation. However, this would not always help the dealer whose performance is not satisfying his franchisor. He might remain unaware that his dealership is in jeopardy and learn of the reasons for its cancellation only after termination has become a fait accompli. The dealer may be saved fron the frymg pan of coercion only to be thrown into the fire of unexpected and unfair termmation.

\section{B. Deference to the Contract.}

Dealers prosecuting ADDCA actions have found it difficult to prove the "wrongful demand" element of coercion. The courts in ADDCA suits have often condoned manufacturers' denaands by finding justification for them in the express terms of the franchise agreements. Despite Congress' intention that ADDCA should "assure a dealer the opportunity to secure a judicial determination irrespective of contract terms as to whether the automobile manufacturer has failed to act in good faith," 44 courts have been willing to find that the manufac-

Cir. 1976); Berry Bros. Buick, Inc. v. General Motors Corp., 257 F. Supp. 542, 546 (E.D. Pa. 1966), affd, 377 F.2d 552 (3d Cir. 1967). The court in Frank Chevrolet Co. v. General Motors Corp., 304 F. Supp. 307, 318 (N.D. Ohio 1968), affd, 419 F.2d 1054 (6th Cir. 1969), offered a somewhat different conception of the three necessary elements of "failure . . . to act in good faith" in refusing to renew the franchise: (1) the manufacturer must have committed an act of bad faith; (2) this act of bad faith must be the direct cause of the nonrenewal; and (3) the nonrenewal must have resulted in loss or damage to the dealer.

In some ADDCA cases, the manufacturer's ostensible reasons for termination are justifiable, but its true motives for cancellation are concealed and imdicate a violation of ADDCA's good faith standard. In these situations, the courts have ignored, or allowed the jury to ignore, the ostensible and false justification and have determined, or allowed the jury to determine, the true reason for termination. The causal link between the demand, threat, and sanction is thereby established. See Autowest, Inc. v. Peugeot, Inc., 434 F.2d 556, 562 (2d Cir. 1970); Mt. Lebanon Motors, Inc. v. Chrysler Corp., 283 F. Supp. 453, 456 (W.D. Pa. 1968), affd, 417 F.2d 622 (3d Cir. 1969). For cases in which the real but disguised reason for termination was the manufacturer's desire to establish "factory stores" in the place of independent franchises, see York ChryslerPlymouth v. Chrysler Credit Corp., 447 F.2d 786, $792-93$ (5th Cir. 1971); Swartz v. Chrysler Motors Corp., 297 F. Supp. 834, $841-42$ (D.N.J. 1969); Madsen v. Chrysler Corp., 261 F. Supp. 488, 506 (N.D. Ill. 1966), vacated as moot, 375 F.2d 773 (7th Cir. 1967).

43. "The cases liave uniformly held that evidence of coercion or intimidation is necessary to a showing of lack of good faitl under the statute, and a mere showing of arbitrary or other bad faith conduct absent coercion is not a sufficient ground for recovery under the Act." Overseas Motors, Inc. v. Import Motors Ltd., 519 F.2d 119, 125 (6th Cir.) (citing cases), cert. denied, 423 U.S. 987 (1975).

44. Alfieri v. Willys Motors, Inc., 227 F. Supp. 627, 629-30 (E.D. Pa. 1964) (emphasis added). 
turers have good reason to terminate when the dealer has materially breached or failed to comply with a material clause of the franchise agreement. The Fifth Circuit has stated the view held generally by the courts:

An automobile manufacturer is not precluded by the Act from including in its contracts with dealers . . . requirements that dealers shall provide product representation commensurate with the good will attached to its trade name and facilitate the proper sale and servicing of its motor vehicles. The manufacturer is entitled to bargin for the protection of its good name, to provide for the trade acceptance of its wares, and to have a reasonable expectation that those who are marketing its cars have the facilities for coping with the sales efforts of those who are dealing $\mathrm{m}$ the products of competitors. . . . We do not think that the good faith requirement, whether viewed in or outside of the context of coercion, prevents a manufacturer from terminating a contract with a dealer where the dealer has, over a long period of time, violated a valid and material clause of the contract and has failed to comply with the continuing insistence of the manufacturer upon performance. ${ }^{45}$

If the federal courts determime ADDCA good faith on the basis of contract provisions, they ignore the imtent of Congress and render ADDCA superfluous. The manufacturer-drafted franchise agreements are the product and sustaining force of the manufacturer's superior bargaining power. To give judicial approval to manufacturer conduct simply because the agreement provides for it is to remforce such superiority.

The ADDCA decisions have frequently dealt with the franchise agreement provision concerning sales responsibility. ${ }^{46}$ The dealer's sales responsibility is often determmed by the use of ratios. Roughly speaking, the ratio of the dealer's sales of a particular model to the total number of new car sales in his district must equal the ratio of total sales of that model in a broader region to the total new car sales in that region. The sales responsibility provisions usually allow for adjustinent of the dealer's quota for "local conditions" and other factors. Courts

45. Woodard v. General Motors Corp., 298 F.2d 121, 128 (5th Cir. 1962). See also Golden Gate Acceptance Corp. v. General Motors Corp., 597 F.2d 676, 680 n.8 (9th Cir. 1979) ("[T]he mere notification by an automobile manufacturer that it expects a dealer to comply with the essential terms of the franchise agreement or face termmation as provided in the contract is not improperly coercive or intimidating"); Garvin v. American Motor Sales Corp., 318 F.2d 518, 520 (3d Cir. 1963) ("manufacturer's insistence on the performance of this contractual commitment could not possibly be considered coercion or intimidation"); Frank Chevrolet Co. v. General Motors Corp., 304 F. Supp. 307, 319 (N.D. Ohio 1968), aff'd, 419 F.2d 1054, 1056 (6th Cir. 1969) ("if the dealer has materially breached the expiring franchise agreement and there has been no waiver of the breach, there is no franchising agreement to be renewed").

46. See Chrysler Motors Corp., supra note 27, at 1; Ford Motor Co., supra note 27, at-3; Chevrolet Motor Div., supra note 27, at 10. 
have held these criteria of sales evaluation reasonable as drafted. ${ }^{47}$ Once a court has accepted the sales evaluation provision as reasonable on its face, it is an easy step to hold that termmation based on the dealer's failure to comply with the contractual sales requirement does not violate the ADDCA's standard of good faith: the manufacturer has made no wrongful demand. ${ }^{48}$

\section{Deference to the Manufacturer's Business Judgment.}

In addition to the courts' deference to the terms of the franchise agreement, judicial acquiescense in the manufacturer's busmess judgment is an obstacle to the dealer's proof of the "wrongful demand" element of coercion under the ADDCA. This acquiescence is a problem for the dealer because he has the burden of proof in establishing coercion. ${ }^{49}$ Under this procedural rule, the manufacturer's actions, unless the dealer proves otherwise, are presumed to have been undertaken in good faith. The dealer's chances of overcoming this burden of proof are lessened by the courts' assumption of an attitude based on a frequently quoted passage in the House Report:

The $[A D D C A]$. . . does not prohibit the manufacturer from terminating or refusing to renew the franchise of a dealer who is not providing the manufacturer with adequate representation. Nor does the bill curtail the manufacturer's right to cancel or not to renew an ineffcient or undesirable dealer's franchise.

47. See Victory Motors of Savannah, Inc. v. Chrysler Motors Corp., 357 F.2d 429 (5th Cir. 1966) (nanufacturer's determination of dealer's ininimum sales responsibility was fair and reasonable); Milos v. Ford Motor Co., 317 F.2d 712, $716-17$ (3d Cir. 1963) ("with respect to sales quotas, the criteria provided in the agreement . . . appear to be eminently reasonable, objective and nondiscriminatory"); Clifford Jacobs Motors, Inc. v. Chrysler Corp., 357 F. Supp. 564, 574 (S.D. Olio 1973) (adjustment of quota to reflect local conditions reinforces finding of its reasonableness and fairness).

48. See Clifford Jacobs Motors, Inc. v. Chrysler Corp., 357 F. Supp. at 574 (termination for failure to achieve minimum sales responsibihty is approved by court even though inanufacturer did not terminate other dealerships that had not obtained it); Leach v. Ford Motor Co., $189 \mathrm{~F}$. Supp. 349, 354 (N.D. Cal. 1960) (court approves termination on the ground that dealer had not for a period of five years measured up to its assigned market potentials, assumed by the court to be reasonable).

Even if a court finds the sales objective to be unreasonable and the demand to meet the objective to be wrongful, a dealer has no cause of action if the inanufacturer neither orders the dealer to "meet the sales objective or be terminated" nor uses substandard sales as a ground for termination. The reason is that an element of coercion is lacking in either case. See text accompanying note 42 supra. See Autohaus Brugger, Inc. v. Saab Motors, Inc., 567 F.2d 901,912 (9th Cir.), cert. denied, 436 U.S. 946 (1978) (manufacturer did not use the fact that dealer failed to meet sales objectives as grounds for nonrenewal or as a means of threatening the dealer to make the sales objective or be terminated).

49. See, e.g., Milos v. Ford Motor Co., 317 F.2d 712, 718 (3d Cir. 1963) (citing S. REP. No. 2073, 84th Cong., 2d Sess. (1956)); Cecil Corley Motor Co. v. General Motors Corp., 380 F. Supp. 819, 844 (M.D. Tenn. 1974). 
The bill does not freeze present channels or methods of automobile distribution . . . .50

Salco Corp. v. General Motors Corp. ${ }^{51}$ demonstrates the judicial respect given to a manufacturer's decisions apart from the terms of the franchise agreement. The plaintiff, Denver Buick, had operated a dealership for many years im downtown Denver. Because the building at this location had become difficult and costly to maintain, the plaintiff considered moving its dealership to a new location. The franchisor, General Motors, determined in a inarket study that the best relocation sites would be im certain parts of the city. Denver Buick found the sites in those areas unsatisfactory and instead requested General Motors' permission to relocate at a suburban location that it believed to be "exemplary in every way." 52 General Motors withheld consent for the move to the suburban location. Eventually, the plaintiff and its franchisor signed a new five-year agreement under which the plaintiff contracted to continue business at the downtown location and not to move or establish a different location without written approval of General Motors. Nonetheless, plaimtiff sold its downtown property and repeated its request to move to the suburban location. General Motors refused to consent to this nove and gave the plaintiff three days to inform General Motors of its "dealership intentions." 33 Subsequently the plaintiff terminated the franchise. In its ADDCA suit, Denver Buick argued that General Motors refused to approve the move to the suburban location because the inanufacturer wanted to protect another Buick dealer, Deane Buick, located nearby. The Tenth Circuit evaluated General Motors' decision by noting that the manufacturer had a vital stake in making sure the market area had adequate coverage to best serve the public.

That General Motors was concerned about protecting Deane does not justify an inference that the decision not to permit Denver Buick to locate to ... [the suburban site] was "unfair." Such a decision was in General Motors' own business interests; that these interests may have also coincided with those of Deane Buick is incidental.

The most that can be said of the controversy is that it was a confict of business judgments: General Motors' desire to establish a [south Denver] franchise against Denver Buick's decision that the location was not acceptable.

... And if as a matter of business judgment General Motors decided that its Denver market would be best served by locating

50. H.R. REP. No. 2850 , at 4603 (emphasis added).

51. 517 F.2d 567 (10th Cir. 1975).

52. $I d$. at 570 .

53. Id. at 571. 
dealerships in each of four quadrants [of Denver], there is nothing as yet in AFDA which deprives it of that right. 54

The courts do not often express in such clear terns their respect for the inanufacturer's business judgment, but this attitude is at least mdirectly indicated in many ADDCA decisions. Manufacturers have received court approval to terminate when in their business judgment the dealer's facilities were inadequate; 55 the dealer failed to inaintain the necessary capital; 56 the dealer was frequently absent from the place of business; 57 the dealer refused to employ additional salesmen or mechanics;"58 or the dealer refused to accede to a plan of "rehabilitation" that the manufacturer in its judginent had urged upon the dealer as the best means of improving substandard performance. ${ }^{59}$ Courts have also held that, absent coercion, the ADDCA does not protect dealers agamst the manufacturer's decision regarding the allocation of certam cars or against the estabhishment of competitive dealerships. The dealer has no right to cars of a certain color, body, or style or to be free from competition from additional dealers. ${ }^{60}$ One court has held that the manufacturer/distributor's decision to renew the dealer's franchise only if the dealer agreed to take on another line of cars was in the best marketing interests of the manufacturer; the court gave no consideration to possible benefits or losses to the dealer froin such a new

54. Id. at 573 (emphasis added). See Golden Gate Acceptance Corp. v. General Motors Corp., 597 F.2d 676, 681 (9th Cir. 1979); Burgin Motor Co. v. American Motor Sales Corp., 449 F. Supp. 842, $851-52$ (D.S.C. 1978).

55. See, e.g., Milos v. Ford Motor Co., 317 F.2d 712 (3d Cir. 1963), cert. denied, 375 U.S. 896 (1963); Staten Island Motors, Inc. v. American Motors Sales Corp., 169 F. Supp. 378, 380 (D.N.J. 1959).

56. See, e.g., Globe Motors, Inc. v. Studebaker-Packard Corp., 328 F.2d 645, 648-49 (3d Cir. 1963); Augusta Rambler Sales, Iuc. v. American Motors Sales Corp., 213 F. Supp. 889 (N.D. Ga. 1963).

57. Kotula v. Ford Motor Co., 338 F.2d 732, 737 (8th Cir. 1964), cert. denied, 380 U.S. 979 (1965); Staten Island Motors, Inc. v. American Motors Sales Corp., 169 F. Supp. 378, 380 (D.N.J. 1959).

58. Kotula v. Ford Motor Co., 338 F.2d at 737.

59. Clifford Jacobs Motors, Inc. v. Chrysler Corp., 357 F. Supp. 564, 573 (S.D. Ohio 1973); Leach v. Ford Motor Co., 189 F. Supp. 349, 354 (N.D. Cal. 1960).

60. See Ed Houser Enterprises, Inc. v. General Motors Corp., 595 F.2d 366, 371 (7th Cir. 1979); Autohaus Brugger, Inc. v. Saab Motors, Inc., 567 F.2d 901, 914 (9th Cir.), cert. denied, 436 U.S. 946 (1978); Southem Rambler Sales, Inc. v. American Motors Corp., 375 F.2d 932, 935-36 (5th Cir.), cert. denied, 389 U.S. 832 (I967); Victory Motors of Savannah, Inc. v. Chrysler Motors Corp., 357 F.2d 429, 432 (5th Cir. 1966); Garvin v. American Motor Sales Corp., 318 F.2d 518, 520 (3d Cir. 1963); Clifford Jacobs Motors, Inc. v. Chrysler Corp., 357 F. Supp. 564, 575 (S.D. Ohio 1973); H.R. REP. No. 2850 , at 4603 (manufacturer is not precluded from appointing an additional dealer in a coinmunity unless the appointment is used as an instrument of coercion and intimidation). But see Martin Motor Sales, Inc. v. Saab-Scania of America, Ine., 452 F. Supp. 1047, 1051 (S.D.N.Y. 1978), affd, 595 F.2d I209 (2d Cir. 1979) (terminating dealer because he refused to buy outdated model cars and "lemons" is one of the "kinds of abuses which Congress attempted to eliminate by passing the Act'). 
arrangement.61

The dealer who attempts to attack the integrity of the inanufacturer's busmess judgment may encounter unexpected resistance from the court. For exainple, one court has used its own analysis of business figures to show the dealer's "submarginal performance."62 Another has affirmed a lower court's holding that, since the dealer failed to complain to the manufacturer that local conditions required a downward adjustment of his "sales efficiency potential," the dealer would not be permitted to raise the issue in court. ${ }^{63}$ Moreover, a dealer may not establish the unfairness of the minimum sales standard by showing that other dealerships that have failed to reach the sales objective were not termmated. Good faith does not require that the manufacturer tèrminate all of the dealers who fall below their objectives; the franchise agreement merely makes termination possible when sales are below the specified level.64 One court has stated that demands that, if fulfilled, would directly benefit a manufacturer but would not benefit the dealer, are suspect under ADDCA's good faith provision. ${ }^{65}$ However, other courts have generally ignored this rule. ${ }^{66}$

\section{Recommendation and Persuasion.}

A fourth reason why autoinobile dealers have had difficulty in prevailing in ADDCA suits is the final exclusive clause in the section one definition of good faith: "Provided, That recommendation, endorsement, exposition, persuasion, urging or argument shall not be deemed to constitutue a lack of good faith."67 One can incorporate the exclusion of these ineans of communication, hereinafter referred to as "persuasion," to the three-element conception of coercion that the courts have employed im ADDCA cases. Persuasion is not coercion either because it is not a "demand" or because it is not backed up with the threat of "sanction." Semantically, persuasion and coercion may be distimct in approach and tone. However, when representatives of the 1974). (1965).

61. David R. McGeorge Car Co. v. Leyland Motor Sales, Inc., 504 F.2d 52, 56 (4th Cir.

62. Kotula v. Ford Motor Co., 338 F.2d 732, 736-37 (8th Cir. 1964), cert. denied, 380 U.S. 979

63. Frank Chevrolet Co. v. General Motors Corp., 304 F. Supp. 307, 315 (N.D. Ohio 1968), affd, 419 F.2d 1054 (6th Cir. 1969).

64. Clifford Jacobs Motors, Inc. v. Chrysler Corp., 357 F. Supp. 564, 575 (S.D. Ohio 1973) (citing with approval Zebelman v. Chrysler Corp., 299 F. Supp. 653, 658 (E.D. Mo. 1968)).

65. Volkswagen Intcramericana, S.A. v. Rohlsen, 360 F.2d 437, 442 (Ist Cir.), cert. denied, 385 U.S. 919 (1966).

66. The rule was cited in Martin Motor Sales, Inc. v. Saab-Scania of America, Inc., $452 \mathrm{~F}$. Supp. 1047, 1051 (S.D.N.Y. 1978), affd per curiam, 595 F.2d 1209 (2d Cir. 1979).

67. 15 U.S.C. \& 1221(e) (1976). 
large and powerful manufacturer "recommend, urge or argue," a dealer inight reasonably perceive such expressions as demands reinforced by tacit threats of termination or other sanctions. Relying on the persuasion exclusion of section 1, the courts have condoned manufacturer communications ranging from innocuous suggestions to thinly veiled ultinatums, and from helpful advice regarding personnel or marketing strategy to harassinent intended to drive the dealer to hostility and ultimate cancellation. ${ }^{68}$ One court has even held that a manufacturer may inform the dealer of its "intention to consider termination" in order to spur the dealer on to compliance with the manufacturer's recoinmendation. ${ }^{69}$

A recommendation intended to improve franchisee performance coupled with a notice that the manufacturer is considermg termmation may be the bitter pill the dealer should swallow for the health of his own enterprise. Nevertheless, few courts have recognized the deleterious effect that the announcement of possible termination has on the dealer's business. In Madsen v. Chrysler Corp. ${ }^{70}$ however, the court did note that "[t]he possibility of termination was clearly a substantial factor in causing this decline [im sales]." 71 To minimize losses in case of termmation, the dealer in Madsen limited credits given to potential buyers for used cars to the amount the cars would yield im a forced litigation. This move put the dealer at a competitive disadvantage. The court also recognized the psychological innpact of the inanufacturer's announceinent of its intention to terminate the dealer's newly expanded franchises: "a cloud has hung over the expanded operation

68. See Victory Motors of Savannah, Inc. v. Chrysler Motors Corp., 357 F.2d 429, 432 (5th Cir. 1966) (representatives of manufacturer insisted that dealer sell more cars, advertise in a certain way, and hire more salesmen); Kotula v. Ford Motor Co., 338 F.2d 732, 736-38 (8th Cir. 1964), cert. denied, 380 U.S. 979 (1965) (representatives of manufacturer used langauge such as "you either take that truck or you're not going to be a Ford Dealer" and "if its [sic] the last thing I ever do, it will be to make you wish you never were a Ford Dealer in your hfe" in the course of "offering rccommendations," "inaking suggestions," and "urging" dealer to adopt better business practices); Clifford Jacobs Motors, Inc. v. Chrysler Corp., 357 F. Supp. 564 (S.D. Ohio 1973) (advertising and sales advice); Leach v. Ford Motor Co., 189 F. Supp. 349, 353-54 (N.D. Cal. 1960) (urging dealer to implement plan increasing number of salesmen and stepping up sales objective is mere recounmendation of a rehabilitation plan).

69. Leach v. Ford Motor Co., 189 F. Supp. 349 (N.D. Cal. 1960).

It could not have been the intent of the Automobile Dealers Franchise Act that a manufacturer should never in advance of termmation indicate to a dealer its dissatisfaction with the dealer's representation over a long period and its intention to consider termination. ...

To construe the Act as requiring a manufacturer to effect termination, if it so chooses, without previous notice to the dealer, or opportunity to consider his situation, would be to make the Act a snare for the dealer rather than a protection. Id. at 354 .

70. 261 F. Supp. 488 (N.D. Ill. 1966), vacated as moot, 375 F.2d 773 (7th Cir. 1967).

71. 261 F. Supp. at 502. 
from the start and no measure of normal performance has been possible." 72

\section{E. Implicit Coercion.}

The three-part test for coercion has left the dealers vulnerable to what may be called "implicit coercion." Implicit coercion may occur when a manufacturer demands that the dealer do something that he has a right not to do, but does not expressly threaten sanction for noncompliance. A court that strictly adheres to the three-part test of coercion must hold that the dealer has no cause of action because the second element of coercion-the threat to impose a sanction-is lacking. Likewise, the manufacturer may wish to cancel a certain dealer for reasons not provided for in the franchise agreement. ${ }^{73}$ To do so, he may force the dealer into default under the franchise agreement and then terminate the dealer according to contractual provision. Or, the manufacturer may drive the dealer into voluntary termination. ${ }^{74}$ The dealer will have no cause of action because the manufacturer made no demand upon him. No coercion will be found.

In either of these situations, strict application of the three-part coercion test would mean that the dealer has no cause of action. However, both sets of circumstances can be perceived as types of implicit coercion. When a large and powerful manufacturer demands that a dealer do something, it is not unreasonable to infer that the manufacturer will resort to enforcement or pumishment if the franchisee ignores the demand. With vastly superior bargaining power and economic strength, the manufacturer does not have to be explicit about the serious consequences that may follow the dealer's failure to comply; the threat is implied. When the franchisor wishes to terminate the dealer for improper reasons, the demand and the threat are implicit but can be verbalized as "terminate yourself; if you don't, we'll force you to, or drive you into default so that we can rightfully terminate you."

According to the legislative history of ADDCA, Congress realized that "[t]he existence of coercion or intimidation depends upon the circumstances arising in each particular case and may be inferred from a

72. $r d$. at 506 .

73. For example, the manufacturer's officer or representative may wish to terminate a dealer because he personally dislikes him, because he wishes to punish him for dealing in products of a competing manufacturer, or in order to replace him with a dealer he prefers for personal or business reasons.

74. For example, the inanufacturer may establish a sales quota that the dealer cannot reasonably be expected to meet. Or the manufacturer may decline to come to the rescue of a financially distressed dealer or refuse to permit transfer of ownership or change in location. The effect of these decisions may be default or self-termination. 
course of conduct."75 The courts have not been very receptive, however, to dealers trying to prove implicit coercion. For exainple, in Clifford Jacobs Motors, Inc. v. Chrysler Corp.,${ }^{76}$ the district court held that the evidence did not support the dealer's allegation that the inanufacturer established and capitalized other dealerships to compete unfairly with the dealer and destroy his business. The court's unsatisfactory reason for rejecting this allegation was that the dealerships were estabhished with the ultimate intent to sell thein to private owners and that inany of the dealerships liad in fact been so sold. ${ }^{77}$ In Garvin v. American Motor Sales Corp. ${ }^{78}$ the plaintiff dealer alleged that the manufacturer established a competing dealership in his area that was a onedealer town, and that the manufacturer failed to assist him in reestabhishing his credit when it was suspended by a lending mstitution. The court responded to these allegations by asserting that "the record is completely devoid of any evidence to show that the new dealership was established as a device to coerce . . . [the dealer] . . . Obviously, [the ADDCA] ... does not require the manufacturer to aid in financing the operations of its dealers." 79

By requiring coercion in order to establish failure to act in good faith, by strictly requiring dealers to show the three elements of coercion, by deferring to the ternns of the franchise contract and to the business judgment of the manufacturers, by giving a broad characterization to perinissible persuasion, and by failing to recognize the inherently coercive nature of some words and actions of the manufacturer, the courts have prevented the Act from achieving its objectives. By quahfying what constitutes a failure to act im good faitli and obliging the plaintiff-dealer to carry the burden of proof, the courts have denied dealers a ineans of bargaining on equal terins with manufacturers and obtaining a remedy, irrespective of contract terıns, for the manufacturers' failures to act in good faith in performing under or terminatimg franchises. As one court noted, "the beneficent balm of protection succoring automobile dealers under the Act has been sparingly and

75. H.R. REP. No. 2850, at 4603 (emphasis added). See also Diehl \& Sons, Inc. v. International Harvester Co., 426 F. Supp. 110, 124 (E.D.N.Y. 1976) (court apparently accepts plaintiff's argument that an implied demand may "be inferred from all the facts and circumstances without a showing of a formal demand").

76. 357 F. Supp. 564 (S.D. Ohio 1973).

77. Id. at 575. For a discussion of the nature of "factory dealerships" and their effect on the independent dealer, see Madsen v. Chrysler Corp., 261 F. Supp. 488, $498-99$ (N.D. Ill. 1966), vacated as moot, 375 F.2d 773 (7th Cir. 1967); L. WHITE, supra note 18, at 167.

78. 318 F.2d 518 (3d Cir. 1963).

79. Id. at 520-21. 
sparsely applied."80 In 1971, a leading authority on the legal aspects of franchising sized up more bluntly the effectiveness of the ADDCA:

[T] he Act stands as a monument to the false hopes of the auto dealers, and as proof of the folly of attempting to create a workable definition of "good faith." . . . Practically speaking, litigation under the Act is an exercise in frustration, and the experience only serves to confirm the principle that ill-conceived legislation can be worse than no legislation at all. ${ }^{81}$

Nevertheless, a few well-reasoned decisions have avoided the traditional deference to franchise agreenent terms and to the manufacturer's business judginent. Some decisions have carefully examined the course of dealings between dealer and manufacturer to determine whether the good faith standard has been violated. Attentive to the legislative purpose of the ADDCA, one court refused to uphold without question contractual provisions and the nanufacturer's assertion of rights under thein: "[in]ere breach of contract by the dealer does not necessarily relieve the inanufacturer of liability under ... [the ADDCA], whlose very purpose was to afford protection against undue bargaining power on the part of the automobile makers."82 In a more recent decision, a district court recognized that, although the ADDCA leaves a manufacturer free to terminate inefficient dealers, it prohibits a manufacturer from using threats of terınination to enhance its bargaining position. ${ }^{83}$

Several courts have scrutinized the inanufacturer's busmess practices and their justification. The opinion of the district court in Madsen v. Chrysler Corp. ${ }^{84}$ contains a full description of the minimum sales responsibility (MSR) provisions in the Clirysler franchise agreement. Demonstrating the provision's inherent flaws as a dealer evaluation device, the opinion states that solnetimes "a dealer may be under or over his MSR while still performing adequately under the circumstances."8s In Swartz v. Chrysler Motors Corp., ${ }^{86}$ the court rejected the use of MSR as a means of evaluating sales performance of the dealer and, using its own ineans of assessing the statistics, concluded that there was a reasonable probability that the dealer might successfully prove that his

80. Southern Rambler Sales, Inc. v. American Motors Corp., 375 F.2d 932, 934 (5th Cir.), cert. denied, 389 U.S. 832 (1967).

81. Brown 791-92.

82. Mt. Lebanon Motors, Inc. v. Chrysler Corp., 283 F. Supp. 453, 456 (W.D. Pa. 1968), aff d, 417 F.2d 622 (3d Cir. 1969).

83. Chinetti-Garthwaite Imports, Inc. v. Ferrari Societa Per Azioni Esercizio Fabbriche Automobili E Corse, 463 F. Supp. 73, 79 (E.D. Pa. 1978).

84. 261 F. Supp. 488 (N.D. Ill. 1966), vacated as moot, 375 F.2d 773 (7th Cir. 1967).

85. 261 F. Supp. at 495 .

86. 297 F. Supp. 834 (D.N.J. 1969) (ruling on preliminary injunction). 
sales performance was satisfactory. ${ }^{87}$ Accordingly, the court held that termination based solely upon sub-MSR achieveinent was unreasonable. ${ }^{88}$ In York Chrysler-Plymouth, Inc. v. Chrysler Credit Corp. ${ }^{89}$ the Fifth Circuit suggested an approach in which the facts in each ADDCA suit should be evaluated on an ad hoc basis to determine if the nanufacturer has failed to act in good faith:

That certain specific conduct has been held not to constitute a violation of the Act in certain cases does not lead to the conclusion that such conduct would not violate the Act in the setting of another case. The actions of the inanufacturer must be considered under the circumstances arising in each particular case. The entire course of dealings between manufacturer and dealer may be considered and it may then be concluded by the jury that the total conduct was violative of the Act. ${ }^{90}$

In the recent case of Marquis v. Chrysler Corp.,91 the Ninth Circuit coinbined some of the concepts of these renegade opinions to form an innovative approach that could breathe new life into the moribund ADDCA.

\section{MARQUIS V. CHRYSLER CORP.}

\section{A. The Facts of the Case.}

Don Marquis Dodge, an independent franchised dealership in Concord, Califorma, operated from 1960 to 1968 under a standard Chrysler franchise agreeinent. The agreeinent provided that Chrysler could terminate on ninety days' notice upon failure of the dealer to perform fully any of his contractual obligations. One of the dealer's obligations was to ineet his "ininimum sales responsibility." The MSR was calculated by inultiplying total new car registrations in the dealer's "sales locality" by the ratio of the nuunber of new Dodges registered in the "sales region" to all new car registrations in the sales region. The franchise agreement stipulated that the manufacturer would adjust minimuin sales responsibility to take into account factors "directly affecting sales opportunity," such as automobile availability, trends in the dealer's sales, and local conditions. Chrysler representatives periodically visited the Marquis dealership to conduct "sales responsibility reviews." During these nieetings the Chrysler representative would in-

87. But see note 62 supra and accompanying text.

88. 297 F. Supp. at 841.

89. 447 F.2d 786 (5th Cir. 1971).

90. Id. at 793. See also Shor-Line Rambler, Inc. v. American Motors Sales Corp., 543 F.2d 601 (7th Cir. 1976); Madsen v. Chrysler Corp., 261 F. Supp. 488 (N.D. Ill. 1966), vacated as moot, 375 F.2d 773 (7th Cir. 1967).

91. 577 F.2d 624 (9th Cir. 1978). 
forn the dealer of his MSR for a certain period, compare it to the dealer's actual sales, and inake recommendations to improve sales. The dealership operated for more than seven years with sub-MSR. Durmg this time Marquis complied with most of the recommendations recorded on the Sales Responsibility Review Forms; for example, in response to Chrysler's suggestions, he purchased his partner's interest in the business, leased additional property as sales facilities, and invested more personal funds in the dealership. Chrysler representatives never informed Marquis that termination of his dealership was imminent as a result of sub-MSR sales, and Chrysler never adjusted the dealership's MSR downward. Six years imto the franchise, Chrysler representatives, without asking Marquis to relocate or telling Marquis that his facility was madequate, sought Marquis's opinion of a nearby lot as a dealership site. Marquis expressed his belief that it was a poor location. After Marquis learned that Chrysler had purchased the site and sought a permit to construct an auto dealership there, Chrysler assured him that the site would not be developed for five to ten years.

After Don Marquis Dodge had operated as a dealership for eight years, Chrysler informed Marquis that it would termmate his franchise in ninety days. Marquis sent a series of letters pleading for reconsideration, but the dealership was terminated. Marquis brought suit in the federal district court agamst Chrysler Motors Corporation and its parent, Chrysler Corporation, alleging, inter alia, that the termmation violated the ADDCA. A verdict for the plaintiff against Chrysler Motors Corporation on the ADDCA claim was upheld by the Court of Appeals for the Ninth Circuit.

Judge Wright's thoughtful and incisive opimion for the court of appeals in Marquis contrasts with earlier decisions that, relying on the reasonableness and applicability of franchise contract terms, gave almost automatic approval to termination for "busmess reasons" and focused on termination as an isolated event. ${ }^{92}$ Judge Wright divided his discussion of the termmation and the statutory duty of good faith into two parts: the manufacturer's assertion that Marquis's sub-MSR sales justified the cancellation, and the course of dealing between Marquis and Chrysler durimg the life of the franchise.

92. But see Frank Chevrolet Co. v. General Motors Corp., 304 F. Supp. 307 (N.D. Ohio 1968), aff d, 419 F.2d 1054 (6th Cir. 1969). The district court in Frank approved the plaintiff's contention that " 'terminating, canceling, or not renewing' [under ADDCA] can and should be interpreted as referring to an act continumg in nature and not one linited to an instant in tine." 304 F. Supp. at 316. However, the court took this to mean that it should examine manufacturer/dealer relations in the period between the manufacturer's notice of its intention not to renew and the final termination date of the franchise. $I d$. 


\section{B. Termination for Sub-Minimum Sales Responsiblity (MSR) Sales.}

The Ninth Circuit refused to accept as autonatically valid the manufacturer's decision to terminate a dealer who failed to live up to contractually formulated sales objectives. While the court reaffirmed the right of the manufacturer to terminate dealers who represent them madequately and who have consistently breached valid and material contract clauses despite the manufacturer's continued insistence on performance, ${ }^{93}$ the court noted that MSR indicates an average performance to which some dealers inust be inferior. Thus, it found that "[t]he nature of MSR renders it suspect as the simgle indicator of satisfactory sales performance."94 In view of the circumstances surrounding the Don Marquis Dodge termination, failure to satisfy minimum sales responsiblity could not be a defense per se to an ADDCA complaimt. "The fact that Marquis' obligation to meet MSR was a term of the concededly valid franchise agreement does not compel the conclusion that Chrysler Motors was free to rely on that provision to terminate the dealership whenever it chose to do so."95 The court held that on the facts of this case

[w] here the dealership operated at sub-MSR levels for a considerable period, during which the sales requirement consistently was treated as a goal, and where there is evidence that termmation was motivated by other reasons, the dealer's failure to satisfy MSR does not by itself establish that sales performance was so poor that termination could not violate the Act.96

\section{Course of Dealing and Good Faith.}

Judge Wright recognized the long line of decisions holding that coercion-defined by the courts as a wrongful demand for which noncoinpliance will result in sanctions-or a threat of coercion is a necessary element of an ADDCA cause of action. But in response to Chrysler's contention that an ADDCA cause of action does not lie unless there is an express wrongful demand enforced by threats of a sanction, Judge Wright denied that the ADDCA conception of good faith was so limited. Instead, the court maintamed that both the wrongful demand and the existence of coercion may be "inferred from a course of conduct."97 Despite this acknowledgement that at least imphicit coercion is required for "failure to act in good faith" under the ADDCA, the court, without explaining the nature of the coercion that took place,

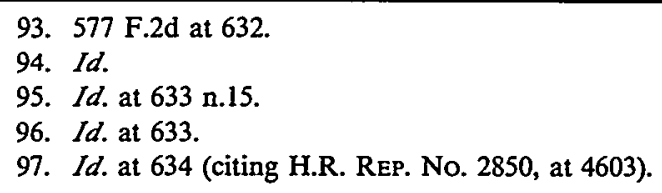


found that Chrysler "breached the statutory duty of good faith."98 Instead of revealing how Chrysler's behavior was coercive, Judge Wright's perceptive opinion demonstrated how two aspects of Chrysler's course of dealing with Don Marquis amounted to a failure to act in good faith-regardless of coercion.

First, the court examined Chrysler's treatment of the contractual MSR provision. The opinion pointed to the fact that, despite the failure of Don Marquis Dodge to achieve its responsibility, Chrysler had not insisted on performance of the MSR provisions or stated that the dealership was subject to immediate termination as a result of subMSR sales. In fact, the periodic sales review ineetings treated minimum sales responsibility "as a goal to be attained through implementation of sales improveinent suggestions." 99 The jury, in deciding the issue of good faith, properly considered the manufacturer's invocation of the contractual right to terminate "after years of acquiescence in the face of low sales." 100 The court cast doubt on the validity of the MSR standard by noting that Don Marquis Dodge's minimum sales responsibility was never adjusted downward, even though there was evidence that certain local conditions impeded the dealer's sales performance. Moreover, the court held that the jury reasonably could have concluded froin the evidence that "Chrysler Motors never intended to adjust MSR as the franchise [agreement] stated it would." 101

The second consideration on which Judge Wright focused his attention was the manufacturer's true motivation in terminating the franchise. Soon after Don Marquis Dodge was terminated, Chrysler constructed a corporate-owned Dodge retail facility on the site that had earlier been acquired and shown to Marquis. The court found that, despite conflicting evidence, the jury could reasonably have concluded that Chrysler had "resolved to take [Marquis] ... out of business when he was unreceptive to relocating." 102

The Marquis decision is noteworthy not only because the court considered the actual application and validity of the contractual provisions and the ulterior, rather than the ostensible, motivations of the terininating manufacturer, but also because the court considered the effect of the manufacturer's harshly inconsistent behavior on the termi-

98. 577 F.2d at 635 .

99. Id. at 634 .

100. Id. at 634 n.16.

101. Id. at 634 .

102. Id. Marquis alleged that the decision to build a corporate-owned dealership nearby was part of a pattern that resulted in the creation of six such factory stores from 1967 to 1969 . These dealerships all incurred tremendous losses through 1970. Reply Brief for Plamtiff-Appellant at 25, Marquis v. Chrysler Corp., 577 F.2d 624 (9th Cir. 1978). 
nated dealer. Because Chrysler allowed Marquis to continue so long in business with sub-MSR sales, never adjusted responsibility to excuse periods of sub-MSR sales, and never threatened, expressly or implicitly, to terminate the dealership for failure to achieve MSR, Marquis could reasonably assume that Chrysler was treating MSR as a goal rather than a strict sales quota. ${ }^{103}$ The court apparently perceived the severe effect of Chrysler's termination decision on the dealer. "The jury considered the motivation, timing and manner of termination to be intimidating and coercive in light of all the facts and circumstances. Chrysler Motors' conduct in this case was precisely the kind of intimidating and overbearing manufacturer conduct that the Act was designed to proscribe."104

Without explicitly rejecting the coercion model as the sole test of "failure to act in good faith," the court seems to have ignored the coercion requirement and to have replaced it with undefined principles of fair dealing in order to conclude that Chrysler was liable under the ADDCA. It would have been preferable if the Ninth Circuit had detiberately broken with the "coercion required" precedent and openly employed a broader interpretation of the ADDCA's definition of good faith. The broader interpretation might have specified what, in addition to coercion, would constitute lack of good faith. Outwardly recognizing the restrictive judicial bounds given ADDCA coverage while covertly avoiding them perpetuates ill-conceived precedent without giving imspiration or guidance for reform.

\section{Possible Amendments to ADDCA}

Since the precedent of the majority interpretation of ADDCA's good faith standard has been firmly established, courts handling automobile dealer suits under ADDCA may not adopt the imıvative approach taken by the Ninth Circuit in Marquis. Therefore, to eliminate the layers of judicial gloss that have prevented the ADDCA from

103. 577 F.2d at 634; ff. Madsen v. Chrysler Corp., 261 F. Supp. 488 (N.D. Ill. 1966), vacated as moot, 375 F.2d 773 (7th Cir. 1967). In Madsen, the court was faced with a situation similar to that in Marquis; the manufacturer treated mirimum sales responsibility as a performance goal rather than as a condition of the franchise agreement. The court in Madsen went further than the Marquis court later would when it held that by such treatment Chrysler waived failure to achieve minimum sales responsibility as a defauIt under the franchise agreement. $261 \mathrm{~F}$. Supp. at 506 . In contrast, the Nimth Circuit in Marquis did not "need [to] determine that the contractual right to terminate for sub-MSR sales was waived before Chrysler Motors' course of conduct in terminating the Agreement can be considered to have been without statutory good faith." 577 F.2d at 634 n.16. But cf. Frank Chevrolet Co. v. General Motors Corp., 304 F. Supp. 307, 319-20 (N.D. Ohio 1968), aff d, 419 F.2d 1054 (6th Cir. 1969) (manufacturer may justify termination by proving an adequate cause even though it did not become known to the manufacturer until after termination).

104. 577 F.2d at 635 . 
equalizing the bargaining power of manufacturer and dealer, Congress must amend the statute to delete the statutory definition of good faith with its limiting provisions.

The vast majority of states have statutes that regulate the automobile franchisor/franchisee relationship. ${ }^{105}$ These statutes, much inore particularized than the ADDCA, prohibit specified conduct by the manufacturer toward its dealers. ${ }^{106}$ One may derive from the state legislation elements that should be imcorporated into the amended federal law. The recommended changes, inspired by state statutes, are as follows: (1) replace the ADDCA's present definition of lack of good faith with a less restricted one; (2) supplement this general standard of conduct by permitting dealer suits for particular kinds of manufacturer behavior; (3) provide expressly that, once the dealer makes a prima facie case, the manufacturer has the burden of proof in defending his conduct; (4) provide expressly for the remedies of injunction and damages, including attorney's fees; and (5) provide expressly that the clauses of the ainended Act are to be hberally construed.

105. See ARIz. Rev. Stat. ANN. § 28-1323.01 (West 1976); ARk. STAT. ANN. \$§ 75-2301 to 2312 (Cum. Supp. 1977); CAL. Veh. Code $\$ \$ 3060-3069$ (West Cum. Supp. 1979); Colo. Rev. Stat. §§ 12-6-101 to 123 (1978); ConN. Gen. Stat. ANN. § 14-67a (West Cum. Supp. 1978); Fla. Srat. ANN. $\S \S 320.60-70$ (West 1975 \& Cum. Supp. 1979), repealed by 1976 Fla. Laws, ch. 76$168, \S 3$ (effective July 1, 1980); GA. CODE ANN. $\$ \S 84-6601$ to 6613 (1979); Haw. Rev. STAT. $\$ \$ 437-1$ to 42 (1976 \& Supp. 1978); lDAHO CODE $\$ \$ 49-2401$ to 2422 (Supp. 1979); IND. CODE ANN. §§ 9-10-1-1 to 5-5 (Burns Cum. Supp. 1979); Iowa Code ANN. §§ 322A.1-.17 (West Cum. Supp. 1979-80); Kan. Stat. AnN. \$\$ 8-2301 to 2323 (1975 \& Cum. Supp. 1978); Ky. Rev. Stat. AnN. $\$ \$ 190.010-.080$ (Baldwin 1976); ME. Rev. Stat. ANN, tit. 10, \$\$ 1171-1186 (West Cum. Supp. 1978); MD. TransP. Code ANN. $\S \S 15-201$ to 213 (1977); Mass. ANN. Laws ch. 93B (Michie/Law. Co-op 1975 \& Supp. 1978); Mich. Comp. LAws ANN. $\$ \$ 445.521-.534$ (Supp. 1979); Minn. Stat. ANN. § 168.27 (West Cum. Supp. 1979); Miss. Code ANN. §§ 63-17-S1 to 139 (1972 \& Cum. Supp. 1978); Mont. Rev. Codes ANN. $§ \S 51-601$ to 615 (Cum. Supp. 1977); Neb. Rev. Stat. $\$ \S 60-1401.01$ to 1435 (1978); Nev. Rev. STat. $\$ \$ 482.36311-.36425$ (1973); N.H. Rev. Stat. ANN. \$§ 357-B:1 to 18 (Supp. 1977); N.M. Stat. ANN. \$§ 57-16-1 to 16 (1978); N.Y. Gen. Bus. Law §§ 195-199 (McKinney 1978 \& Cum. Supp. 1978); N.C. GeN. STat. $§ \S 20-285$ to 308 (1975); N.D. CENT. CODE $\$ \S 51-07-01$ to 03 (1974 \& Supp. 1977); Ohio Rev. Code ANN. $\S \S 1333.71-.81$ (Page Supp. 1978); OKLa. Stat. ANN. tit. 47, §§ 561-577 (West Cum. Supp. 197879); Pa. Stat. ANN. tit. 63, \$\$ 801-816 (Purdon Cum. Supp. 1979-80); R.1. Gen. Laws $\$ \$ 31-5.1-1$ to 17 (Cum. Supp. 1978); S.C. Code $\$ \S 56-15-10$ to 130 (1976); S.D. CoMPILEd LAws ANN. \$\$ 326A-1 to 16 (1976); Tenn. Code Ann. $\$ \$ 59-1702$ to 1722 (Cum. Supp. 1978); Tex. Rev. Civ. Stat. AnN. art. 4413(36), \$\$ 4.01-7.01 (Vernon 1976 \& Cum. Supp. 1978-79); UTAH Code ANN. $\S \S 41-3-2$ to 27 (1970 \& Supp. 1979); VA. CODE $\$ \S 46.1-516$ to 550 (1974 \& Cum. Supp. 1979); Wash. Rev. Code AnN. $\$ \$ 46.70 .005-.920$ (Supp. 1978); W. VA. Code $\$ \$ 47-17-1$ to 10 (Cum. Supp. 1979); WIS. Stat. ANN. § 218.01(3)(17) (West Cum. Supp. 1979-80).

106. Most of the state automobile franchise statutes provide for the licensing of manufacturers and dealers, the revocation of licenses for certain conduct, and criminal sanctions to be imposed on the manufacturer or dealer for his commission of particular acts. 


\section{A. The New Standard and Guidelines.}

The amended ADDCA should establish a general standard of manufacturer conduct without the use of definitions, restrictions, or provisos such as those presently contained in the ADDCA. This standard should be supplemented by a hist of particular manufacturer practices that will give rise to recovery by an mjured dealer. In addition, the statute should provide a nonexclusive hist of criteria that the courts should consider im determining whether the manufacturer has violated the standard of conduct or has committed one of the acts that will make it liable to the dealer.

The Massachusetts Act $^{107}$ mcludes all of these provisions and could be used as a model for this portion of the amended ADDCA. 108 With respect to the manufacturer's general standard of conduct, section 4(1) of the Massachusetts Act outlaws any manufacturer action "which is arbitrary, in bad faith, or unconscionable and which causes damage to . . . [the dealer]." 109 One of the greatest advantages of this broad provision is the absence of any definition of the terms "arbitrary," "bad

107. Mass. ANn. Laws ch. 93B (Michie/Law. Co-op 1975 \& Supp. 1978). For an explanation of the Massachusetts Act, see Brown.

108. Many other state statutes contain thorough provisions on the manufacturer's standard of conduct, prohibited manufacturer practices, and guidelines to aid in the determination of whether violations have occurred. E.g., ARIz. Rev. STAT. ANN. \$§ 28-1323(A)(8), -1323.01 (West 1976); Ark. Stat. ANN. $\S \S 75-2305$ (3) to 2305(4) (Cuin. Supp. 1977); Cal. Veh. Code $\$ \S 3060-3063$ (West Supp. 1979); Colo. Rev. Stat. $\$ \S 12-6-118,-120$ (1978); Fla. Stat. AnN. $\$ 320.64$ (West 1975), repealed by 1976 Fla. Laws ch. 76-168, § 3(2)(e) (effective July 1, 1980); GA. CODE ANN. $\$ \S 84-6610(\mathrm{e})$ to $6610(\mathrm{f})$ (1979); HAW. REV. STAT. $\$ \S 437-28(\mathrm{~b})(22),-33$ (1976); IDAHO CODE $\S \S 49-2414(7)$ to 2414(8) (Supp. 1979); IND. CoDE ANN. § 9-10-3-2 (Burns Cum. Supp. 1979); Iowa Code ANN. $\S \S 322 A .2-5, .11, .15, .16$ (West Cum. Supp. 1979-80); Kan. STAT. ANN. § 82308(a)(13) (1975); Ky. Rev. StAT. ANN. $\$ \$ 190.040(1)(1 n)-.040(1)(0), .070$ (Baldwin 1976); ME. Rev. Stat. ANN. tit. 10, $\S 1174(1)-1174(3), 1177$ (West Cum. Supp. 1978); MD. Transp. Code ANN. $\S \S 15-207$ to 209, -211 (1977); MICH. CoMp. LAws ANN. \$§ 445.522-.530 (Supp. 1979); Minn. Stat. ANN. $\S 168.27$ (West Supp. 1979); Miss. Code ANN. \$§63-17-73(1)(c)-63-1773(1)(d) (1972); Mont. Rev. Codes AnN. $\$ \S 51-605$ to 606 (Cuin. Supp. 1977); Neb. Rev. Stat. $\$ \S 60-1420,-1422,-1429,-1433,-1434$ (1978); Nev. Rev. STAT. $\$ \S 482.36351, .3636, .36365$, $.36371, .3638, .36385, .36391, .36395$ (1977); N.H. Rev. STAT. ANN. $\$ \$ 357-B: 4(I)$ to (III), :7 (Supp. 1977); N.M. Stat. ANN. \$§ 57-16-5, -8 (1978); N.Y. GeN. Bus. LAw $\S \S 197,197-a$ (McKinney 1978); N.C. Gen. Stat. §§ 20-305, -305.2 (1975); N.D. Cent. Code § 51-07-01.1 (Supp. 1977); Ohio Rev. Code AnN. $\S \S 1333.72, .73$ (Page Supp. 1978); Okla. Stat. AnN. tit. 47, $\S \S 565(i)$, 565(j), 569(a), 571 (West Cum. Supp. 1978-79); PA. StAT. ANN. tit. 63, §§ 805(2)(xi), 805(2)(xiii), 805(2)(xiv) (Purdon Cum. Supp. 1979-80); R.1. GEN. Laws $\$ \S 31-5.1-4,-7$ (Cun. Supp. 1978); S.C. CODE $\$ \S 56-15-40(1)$ to $40(3),-70$ (1976); S.D. COMPILED LAWS ANN. $\$ \S 32-6 A-3$ to $-7,-14$ (1976); Tenn. Code Ann. \$ 59-1714(c) (Cum. Supp. 1978); Tex. Rev. Civ. Stat. ANn. art. 4413(36), $\S 5.02$ (Vernon 1976 \& Cum. Supp. 1978-79); UTAH CODE ANN. § 41-3-23(c) (1970); VA. CODE $\S \S 46.1-547,-547.2$ (1974 \& Cum. Supp. 1979); Wash. Rev. Code ANN. $\$ 46.70 .180(10)$ (Supp. 1978); W. VA. CoDE §47-1-5 (Cum. Supp. 1979); Wis. Stat. AnN. § 218.01(3)(a)(15), $.01(3)(\mathrm{a})(16), .01(3)(\mathrm{a})(17), .01(3)(\mathrm{a})(23), .01(3)(\mathrm{a})(24)$ (West Cuin. Supp. 1979-80).

109. Mass. ANN. Laws ch. 93B, § 4(1) (Michie/Law. Co-op 1975). 
faith," or "unconscionable," "thus affording broad discretion to the courts in interpreting and applying these terms." 110 Section 7 of the Massachusetts Act makes it unlawful to impose, directly or indirectly, "unreasonable restrictions" on the dealer in the areas of transfer, sale, right to renew, termination, discipline, noncompetition covenants, site control, compliance witl subjective standards, and assertion of legal or equitable rights."11 Section 7 is directed to those "sources of leverage which have individually and collectively contributed to the dominance of the manufacturers over their dealers."112

The Massachusetts Act expressly prohibits certain manufacturer practices. Section 4(2) makes it illegal for a manufacturer to coerce or attempt to coerce a dealer to order unwanted vehicles, parts, or accessories, or any special features not included in the publicly advertised list price of the vehicle. Unlike the ADDCA, the Massachusetts statute makes no exception for "recommendation, endorsement, exposition, persuasion, urging or argument," 113 and thereby recogmizes the implicit coercion present in "persuasion." Section 4(3) of the Massachusetts Act "embodies a true 'Bill of Rights' governing the dealers' relationship with the auto manufacturers," 114 designating specific practices that violate the Massachusetts Act's general prohibition against "[u]nfair methods of coinpetition and unfair or deceptive acts or practices . . ."115 Under an ADDCA amended along the Massachusetts lines, a dealer would have a cause of action for being the victim of any of the following manufacturer abuses:

(1) adoption of a plan for the allocation and distribution of new cars that is arbitrary or unfair,

(2) refusal to deliver cars to the dealer in reasonable quantities and within a reasonable time after receipt of the dealer's order (except when a shortage or delay is due to acts beyond the manufacturer's control);

(3) coercion of or an attempt to coerce the dealer to enter into an agreement or to do any act prejudicial to the dealer by threatening to cancel the franchise;

(4) terinination or failure to renew a dealer's franchise without good cause or offering a renewal on arbitrarily and substantially differ-

110. Brown 796.

111. Mass. Ann. Laws ch. 93B, $\S 7$ (Michie/Law. Co-op 1975).

112. Brown 810 .

113. 15 U.S.C. $§ 1221(\mathrm{e})(1976)$.

114. Brown 799.

115. Mass. ANN. Laws ch. 93B, \& 3(a) (Michie/Law. Co-op 1975). 
ent terms without good cause; 116

(5) unreasonable and unfair discrimination against a dealer in establishing prices for cars, parts, or accessories;

(6) imposition of unreasonable restrictions on a dealer regarding the financial structure of the dealership or the right of the dealer to transfer an interest in the dealership; ${ }^{117}$

(7) obtaining kickbacks from supphers of goods to the dealer;

(8) ownership and operation, either directly or indirectly, of a dealership of the same line make within the relevant market area of a dealer;

(9) arbitrary entrance into a franchise agreennent with an additional franchisee who will operate within the relevant market area of an existing franchise representimg the same line make; 118

(10) coercion of a dealer to assent to a release, assignment, novation, waiver, or estoppel that would release a manufacturer under the ADDCA.

Though one can classify most complaimts brought under the ADDCA into one or more of these categories, this hist of inanufacturer practices should not be an exclusive enumeration of franchisor abuses for which a dealer could bring suit. A manufacturer's superior economic power inay foster additional forms of unfair conduct; and the broad language of a general standard of conduct should cover the manufacturer and make it liable when it engages in any action that is arbi-

116. In determining whether good cause has been established for terminating, refusing to renew, or offering a renewal on substantially different terms, the court should consider all relevant circumstances, including but not linited to: (a) the amount of business transacted by the dealer in the previous three years compared to the busmess available to it; (b) the investinent necessarily made and the obligations incurred by the dealer to perform its obligations under the franchise agreement; (c) the permanency of the dealer's investunent; (d) whether the dealer has adequate car sales and service facilities, equipment, parts, and qualified personnel reasonably to provide for the needs of consumers; (e) whether the dealer has been rendering adequate services to the public; and (f) the existence and inateriality of any breaches by the dealer of the terms of the franchise agreement or applicable law.

117. A manufacturer may require a dealer to identify all persons holding interests in the dealership and may establish reasonable standards concerning the capital needed for dealership operations and the continuity of dealership management.

118. In determining whether the proposed addition of the franchise is arbitrary, the court could consider all relevant circumstances including but not hmited to: (a) whether the establishment of the additional franchise appeared to be warranted by econoinic and inarketing conditions; (b) the retail sales and service business transacted in the last three years by the complaining dealer; (c) the investinent inade and the obligations incurred by the complaining dealer to perform its obligations under the existing agreement; (d) the permanency of the investment of the complaining dealer; (e) whether the complaining dealer is providing adequate competition and convenient consuner care; and ( $f$ ) whether the complaining dealer has adequate car sales and service facilities, equipment, vehicle parts, and qualified personnel reasonably to provide for the needs of the consuiner. 
trary, in bad faith, or unconscionable and that causes damages to the dealer. By replacing the ADDCA's good faith provision with the Massachusetts-type standard of conduct and list of actionable practices and guidelines, Congress will substantially lessen if not eliminate the probleins that have crippled the ADDCA's effectiveness-the threepart coercion requirement, deference to contract terms and to inanufacturers' business judgments, and failure to recognize the coercive character of manufacturers" "persuasion."

\section{B. Burden of Proof.}

The amended ADDCA should provide that, once the dealer has unade a prima facie showing that his franchisor has violated the general standard of conduct or has engaged in one of the actionable practices, the manufacturer will have the burden of proving the contrary. Provisions in several state statutes allocate the burden of proof in this way. ${ }^{119}$ There are at least three reasons why this allocation is advisable. First, particularly in cases of termination, the manufacturer's decision is at the root of the litigation. The knowledge and information upon which the manufacturer bases its decision are more accessible to the manufacturer than to the dealer. Second, placing the burden of proof on the manufacturer, and thereby compelling it to produce evidence that justifies its conduct, would result in a greater pool of facts from which the trier of fact could more competently assess the fairness of the manufacturer's action. Third, by requiring the manufacturer to establish the propriety of his conduct toward the dealer, courts are less likely to impute to the manufacturer possible justification based on contract or business judgment. Instead, the courts and juries will be obliged to consider and judge the reasons expressly alleged by the inanufacturer. In general, shifting the burden of proof from the plaintiff-dealer to the defendant-manufacturer is an imdirect means of equalizing their bargaining power.

\section{Remedies.}

In the area of remedies, the ADDCA would require only a few ininor changes. Although the courts have interpreted the ADDCA as

119. E.g., FLA. STAT. ANN. $\$ 320.697$ (West 1975), repealed by 1976 Fla. Laws ch. 76-168, 33 (effective July 1, 1980); Iowa Code ANN. $\$ 322 A .9$ (West Cum. Supp. 1979-80); Kan. STAT. ANN. § 8-2318(c) (1975 \& Cum. Supp. 1978); Mont. Rev. Codes ANN. § 51-605(8) (Cum. Supp. 1977); Neb. Rev. Stat. \$ 60-1427 (1978); Nev. Rev. Stat. \$ 482.3636(1) (1977); OkLa. Stat. AnN. tit. 47, § 569(c) (West Cum. Supp. 1978-79); PA. Stat. ANN. tit. 63, \$ 805(2)(xi) (Purdon Cum. Supp. 1979-80); S.D. CoMpiled LAWS ANN. § 32-6A-12 (1976); W. VA. CODE $\$ \S 47-17-5(a),-6$ (Cum. Supp. 1979). 
allowing dealers to sue for injunctions against "bad faith" termination of the franchise or other failures of the manufacturers to act in good faith, ${ }^{120}$ an ainended ADDCA should expressly provide for suits for mjunctions as well as for suits for damages. Many of the state automobile franchise statutes possess this feature. ${ }^{121}$ Second, if the dealer prevails in his action against the manufacturer, he should be entitled to recover attorney's fees related to his ADDCA suit, as many state statutes provide. ${ }^{122}$ By allowing recovery of attorney's fees, the ADDCA would help to prevent the great disparity between dealer and inanufacturer resources allocable to legal expenses from discouragmg potential suits. Further, providing attorney's fees to the successful plaintiffdealer would protect his recovery from being consumed by legal expenses. Such a provision in the ADDCA would encourage dealers injured by abusive manufacturer practices to enforce ADDCA prohibitions and carry out the congressional pohicy agamst overbearing and unfair manufacturer behavior. The allowance of attorney's fees may also be justified as a penalty imposed on the manufacturer for noncompliance with a federal statute enacted under Congress' power to regulate interstate commerce.

\section{Liberal Construction.}

In order to free the ADDCA from the tradition of strict construction that the courts have established in interpreting and applying some of its provisions, Congress might preface the aunended ADDCA with a section that provides that courts should liberally construe the Act in hight of its purpose-equalization of the bargaining power between au-

120. See text accompanying note 36 supra.

121. E.g., Fla. Stat. ANN. $\$ 320.695$ (West 1975 \& Cum. Supp. 1979), repealed by 1976 Fla. Laws ch. 76-168, § 3 (effective July 1, 1980); HAw. REv. STAT. § 437-36 (1976); IND. CodE ANN. § 9-10-5-5 (Burns Cum. Supp. 1979); Kan. Stat. ANN. § 8-2315 (1975); ME. Rev. STat. AnN. tit. 10, $\$ 1173$ (West Cum. Supp. 1978); Mass. ANN. Laws ch. 93B, § 12A (Michie/Law. Co-op Supp. 1978); Mich. Comp. LAwS ANN. § 445.534 (Supp. 1979); Nev. Rev. STAT. § 482.36411(1) (1977); N.H. Rev. Stat. ANN. § 357-B:3(11) (Supp. 1977); N.M. Stat. ANN. § 57-16-11 (1978); N.Y. GeN. Bus. Law $\S 198$ (McKinney Supp. 1978); OHio Rev. Code ANN. § 1333.74 (Page Supp. 1978); OKLA. Stat. ANN. tit. 47, § 567 (West Cum. Supp. 1978-79); S.C. CODE $§ 56-15-40$ (3)(c) (1976); Wash. Rev. Code ANN. \$ 46.70.190 (Supp. 1978); W. VA. Code § 47-17-6 (Cum. Supp. 1979).

122. E.g., Ark. Stat. ANn. \$75-2309 (Cum. Supp. 1977); Colo. Rev. Stat. \$ 12-6-122 (1973); FLA. STAT. ANN. $\$ \$ 320.641(4), 320.697$ (West 1975), repealed by 1976 Fla. Laws ch. 76168, § 3 (effective July 1, 1980); GA. Code ANN. § 84-6612 (1979); IND. CodE ANN. § 9-10-5-5 (Burns Cum. Supp. 1979); Md. TRANSP. Code ANN. $\$ 15-213$ (1977); Mich. CoMP. LAws ANN. $\S 445.533$ (Supp. 1979); Miss. Code ANN. § 63-17-101 (1972); Mont. Rev. Codes ANN. § 51-607 (Cum. Supp. 1977); Nev. Rev. STAT. § 482.36411(2) (1973); N.M. STAT. ANN. § 57-16-13 (1978); Okla. Stat. ANn. tit. 47, § 565(j)(4) (West Supp. 1978-79); Pa. Stat. AnN. tit. 63, $\$ 812.1$ (Purdon Cum. Supp. 1979-80); S.C. CoDE § 56-15-110 (1977); WASH. REV. CODE ANN. § 46.70-190 (Supp. 1978); Wis. STAT. ANN. $\$ 218.01(9)$ (West Cum. Supp. 1979-80). 
tomobile manufacturers and dealers. Such a provision would help elimmate the judicial tendency to defer to the manufacturers' business judgments and the manufacturers' contract terms.

\section{CONCLUSION}

Poor drafting and restrictive judicial interpretation have damned the ADDCA. In a sinall minority of cases, including the recent $\mathrm{Mar}$ quis decision, courts have attempted to give the ADDCA the force it needs to equalize the bargaining power of autoinobile manufacturer and dealer. It is doubtful, however, whether this minority approach will ever overcome the inherent flaws of the ADDCA's definition of good faith or the restrictive effect of firmly entrenched judicial precedent. ${ }^{123}$ Only statutory overhaul by Congress can cure the ADDCA's ills. Rehabilitation of the ADDCA would be effective if it incorporated the provisions that are included in many parallel state statutes. ${ }^{124}$

John H. Pavloff

123. Two 1979 cases provide encouraging indications that the judicial precedent has not totally emasculated the ADDCA. In Sherman v. British Leyland Motors, Ltd., 601 F.2d 429 (9th Cir. 1979), the court, citing Marquis, held that "[a] wrongful demand can be implicit, inferable from facts and circumstances without any showing of a formal one." Id. at 446. The court also found that the evidence showed "at least implied threats." Id. The Tenth Circuit has held that the improper and coercive demands to which the ADDCA is directed may occur either before or after the formal execution of the franchise agreement. Colonial Ford, Inc. v. Ford Motor Co., 592 F.2d 1126, 1128 (10th Cir. 1979).

124. Several of the state automobile franchise statutes and the Puerto Rico statute provide for liberal construction. E.g., Haw. Rev. Stat. $\$ 437-41$ (1976); OkLa. Stat. ANn. tit. 47, § 573 (West Cum. Supp. 1978-79); P.R. Laws ANN. tit. 10, § 278c (Supp. 1976). 